\title{
MEDICAL RESPONSIBILITIES IN A FORCE PREPARING FOR OVERSEAS
}

\author{
Colonel A. D. YOUNG \\ D.S.O., M.B., late R.A.M.C.
}

THE background situation to this paper is that a new field ambulance commander has been posted to a brigade which is under orders for a tropical country, on an unaccompanied tour, in three months' time. The aim of the paper is to look at the situation through the eyes of this new officer and to examine how he appreciates it and makes his plans.

He must first ask himself the questions: "Who am I?" and "What is my job?". The answers are that he is the Commanding Officer of a Field Ambulance and Senior Medical Officer of a Brigade. In the first instance his job is the same as a commanding officer of any other unit: he is responsible for the training, administration and welfare of all ranks of the field ambulance and has financial responsibility for stores, vehicles, buildings and so on. To be successful in any given task he will require to have the right personnel, i.e. well-trained, disciplined, and of high morale, the right transport and the right equipment, at the right place and at the right time. As senior medical officer of the brigade he is responsible to the brigade commander for advice on medical matters affecting the brigade, and the individual officers and other ranks in it, and for the technical administration and support of the Regimental Medical Officers. Hc may be required to assist in the training of regimental medical personnel.

Before joining the field ambulance he can almost certainly make the assumption that it will be under strength, particularly in medical officers, and that new personnel are being posted in to bring it up to establishment. Most of these, and especially the medical officers, will have little or no field knowledge. Under these circumstances the success or failure of the field ambulance is going to depend almost entirely upon the commanding officer. He will best overcome the difficulties by ensuring that he personally gives adequate instruction to his officers. On joining the field ambulance the first thing he will do is ascertain the personnel, transport and equipment state and initiate action to obtain his entitlements.

As senior medical officer of the brigade he should report to the brigade commander within 24 hours of joining the field ambulance. Within 7 days he should visit the other commanding officers in the brigade. At his first meeting with the brigade commander and the brigade staff he will receive up-to-date infcrmation about the brigade's future tasks: He will also learn a good deal about any weaknesses there are in the field ambulance. He would mention the various medical problems affecting the brigade as a whole and obtain general approval for a plan of action. He would also let the brigade commander have his first thoughts on the state of the field ambulance and what steps he proposed taking to prepare it for its future tasks. Clearly he must start on the right footing with the brigade commander and his staff. To do this he must ever have in mind that the brigade commander commands the whole brigade, including the field ambulance, and that orders are issued by his staff on his behalf. The brigade commander'has a right to expect his loyalty and it must be given without question. This is amply repaid by the trust given to the senior medical officer.

In visiting the other commanding officers in the brigade the purpose of the senior 
medical officer is to introduce himself to them and to find out if they have any problems affecting him. He should ensure that the battalion commanders are satisfied with their regimental medical officers and that the latter are happy in their work. On an other occasion he would go into the problems of individual regimental medical officers.

\section{Duties of Senior Medical Officer of the Brigade}

At this stage the duties of the senior medical officer are all concerned with going overseas and with the anticipated situation on arrival there. They are best summarised under the following nine headings:

Brigade Medical Standing Orders. All ranks must know of the likely health hazards to be encountered and of the actions necessary to promote and maintain health and avoid disease. Short and concise brigade medical standing orders have therefore to be prepared. As they are related to discipline they should be signed by the brigade commander or by one of his staff on his behalf. The main points forming the basis of these orders are: $a$. Climate (not forgetting the man-power losses which can be caused by severe sun-burn). $b$. Water. $c$. Food. $d$. Disposal of waste. $e$. Insect control. $f$. Prevention of prevalent diseases, including venereal diseases.

All ranks of correct medical category. A check must be made to ensure that all ranks are of the correct medical category to proceed overseas. This is so obvious that it is easily overlooked. Particular attention should be paid to any individual with a history of psychiatric illness, especially if he has been downgraded and then subsequently upgraded. The effect of stress upon such an individual has to be carefully considered.

Vaccination state. The vaccination state of all ranks must be brought up-to-date. This may be quite a big task and may best be carried out by teams of medical officers holding sessions in the various units of the brigade. As yellow fever vaccination is necessary ample warning must be given to the pathologist concerned and a programme drawn up with his agreement.

Dental fitness. It is a big mistake to take for granted that all ranks in the brigade are dentally fit. The actual dental state must be ascertained and a plan of priorities for treatment has to be arranged. The DDS Command may have to be asked for help in addition to the field ambulance dental officer. Bearing this very considerable problem in mind will also ensure that the dental officer is not allotted other duties for the time being.

Regimental medical equipment. The regimental medical officers must have the equipment to which they are entitled and it must be serviceable. This applies not only to purely medical equipment but also to transport, stretchers, blankets lighting and tentage.

Regimental medical personnel. Units in the brigade must have their entitlement of stretcher-bearers, medical orderlies, water duty and sanitary personnel and they must be properly trained. There may be an additional need for anti-malarial squads. If necessary, short intensive courses will have to be carried out in the field ambulance.

Water vehicles and containers. Water vehicles and trailers must be up to scale, fully equipped, and in working order. Units must have their entitlement of serviceable water containers.

First aid training of all ranks. A considerable amount of practical first aid knowledge can be put across in one hour. The senior medical officer himself should give such a talk/ demonstration to the officers of the brigade staff and this can usually be arranged in the Brigade mess some evening after supper. This will not only teach the officers concerned, 
but will also get them interested in the importance of the subject to all ranks of the brigade. The talk should stress the importance of wound shock and those factors which aggravate it-continuing haemorrhage, pain, hunger and fatigue. Maintenance of an airway, artificial respiration, application of dressings, arrest of haemorrhage, and simple body splinting with triangular bandages and padding should be taught. All medical officers of the field ambulance, as well as the regimental medical officers, will require to give similar talks to all ranks throughout the brigade.

Health hazards overseas. Talks, based on brigade medical standing orders, should be given to all ranks in the brigade. The purpose of them is to show that each and every hazard is preventable by following certain simple rules.

\section{Duties of Field Ambulance Commanding Officer}

In order to assume command the field ambulance commanding officer has to take over from his predecessor and it is up to him how he does this. A reasonable method is to have a board of officers checking $100 \%$ of controlled stores and $10 \%$ of other stores. This is not a right but can usually be arranged. In addition he should do spot checks in each store, should ensure that the imprest and regimental accounts are balanced and correct, and that fidelity insurance policies are in being for adequate amounts. The transaction is completed by the signing of handover/takeover certificates.

The Commanding Officer has now to appreciate very quickly the training and administrative state of his Unit and to ensure that he has got everything to enable him to deal with the tasks he has been given to expect overseas.

From the beginning he should allot a high priority to the training of his officers, with especial reference to the newly joined medical officers. It would be a great mistake to take for granted that these officers will know the elementary things expected of officers in a field unit, and to reprimand them when their ignorance is uncovered is not helping them or the efficiency of the Unit. Many of them will never have served outside of a hospital or static medical centre and are now, as section officers, being given command of men whom they have to lead and care for. Their instruction is a prime responsibility of the commanding officer and will almost certainly have to be done outside of normal working hours. A good start would be made using two evenings a week, for four weeks, for this purpose. Subjects to be covered would include:

Organisation and function of the field ambulance. This entails translating the establishment into functional terms. The commanding officer would particularly stress those points which are seldom thought of by the inexperienced: the need for mobility and improvisation, the fact that living in the field is devoid of such civilised amenities as water on tap, water-borne sewage, electric light at a press of a switch, and that the reception of a field medical unit is quite unlike the glass window at the entrance of a hospital with a pretty girl sitting behind it. He would emphasise the essential division of a field medical unit into three parts, reception, treatment and evacuation, and explain the necessity for this. He would stress particularly that reception is a large sheltered area, almost devoid of equipment, which will allow of a large number of casualties being received at one time. Casualties are not kept here, but it is here they are sorted. It is an all-important part of the unit and requires competent doctors and good lighting around the clock. He would explain the vital need for stretchers and blankets at all times. Economy of personnel and transport would be brought out and the need for reserves at all levels underlined. Particular tasks likely to be met with overseas would be discussed. The unit might be dispersed 
over a considerable area and medical care of the indigenous population might have to be undertaken. Sections would need to function on their own and section officers must be constantly anticipating their requirements of both personnel and equipment. Nothing must ever be taken for granted.

Man-management. The British soldier is second to none and the term includes the soldiers of the medical services. A peculiar and traditional mixture of leadership, discipline, loyalty and care exists between British officers and their men and this what man-management is about. An officer's first duty is to his men and this goes hard with the officer who has only ever thought of himself. The officer starts his apprenticeship in manmanagement by deliberately assimilating facts about his men: where they come from, married or single, age, if married what children and their ages and names, educational standard, civilian jobs before joining the Army, hobbies, pay. In days gene by young officers were brought up on catch phrases like "There are no bad men, only, bad officers," "Don't be sarcastic with, or swear at, those below you: they can't hit back", "Don't tell your men smutty stories: they may laugh at the time but you will have lost any respect they ever had for you". These, and similar injunctions, may sound old-fashioned, but they are as necessary today as ever they were. An officer has to ensure that the men under his command are gainfully employed and live and work under the best conditions available under prevailing circumstances. $\mathrm{He}$ is also responsible for training his men, and above all, he is their leader and must lead by example and with the confidence derived from knowing his job.

There is perhaps a tendency to confuse good man-management and cheap popularity. An officer must never do anything in order to be thought a "good chap". This attitude too often leads to injustice to others.

Administration of discipline. Officers must know the elements of Military Law and their place in its administration. They must be just and impartial and have no favourites. They should know the main legal points concerned with duties in aid of the Civil Power.

Organisation and function of the brigade. This talk is best given by an officer of the brigade staff. It should be very elementary and should include an outline of the titles and duties of the principal staff officers.

Communications. All officers must learn how to speak on wireless. This lecture/ demonstration would be given by a Royal Signals Officer and it would be an advantage to have the senior nco's of the Unit at it as well as the officers.

Specialists talks. If time permits it may be worthwhile inviting specialists in Medicine, Surgery, Nursing, Psychiatry and Army Health to come to the unit and talk about their own aspects of its future role. Such talks should be pitched at field ambulance, as opposed to hospital level and should consist more of practical points than of general theory. At all these evening talks the regimental medical officers would be most welcome. By the time all the subjects have been dealt with the commanding officer should know all his officers quite well, and vice versa. He would also be concerned about their professional training and would examine the possibility of correspondence courses for those officers hoping to take up a specialty. In addition he would co-ordinate the text books being taken overseas by individual officers and so ensure that a fairly comprehensive library was available.

Coincidental with his duties as senior medical officer of the brigade, and his evening 
classes for officers, the commanding officer would be appraising and overhauling the administration and training of the field ambulance as a whole. Fortunately much of the detail can be taken off his shoulders by the second-in-command and the non-medical officers but he must dictate the policy. The aim of good administration is to produce a happy and efficient unit and good personnel administration is obviously essential. A welltrained unit is not efficient unless it possesses high morale, and high morale is achieved by good leadership and the firm belief that the job in hand is well worthwhile. Administration is not, however, entirely concerned with personnel but includes the whole ' $Q$ ' side, and transport and equipment have to be kept in a high state of serviceability. In outline, the points that the commanding officer will be concerned about are as follows:

Time-Table of events. A plan has to be prepared showing what has to be done and when, and who is responsible for what. This plan is conveniently made by taking the day of readiness as D-Day and working back from that. For example, leave might be from D-20 to D-7.

Briefing of all ranks. All ranks must be told as soon as possible what is going to happen and why. They should also be told what leave is going to be given and when. The new postal address should be announced as soon as possible. If there are security considerations about the move overseas these should be stressed at this briefing. The commanding officer should address all ranks himself on this occasion and should make his talk something of a morale-raiser.

Distribution of personnel, transport and equipment. Unfortunately neither the establishment nor equipment tables of the unit show the functional distribution of personnel, equipment and transport. The necessary tables must be prepared and issued to all concerned.

Next of kin. Details of next of kin of all ranks must be recorded on a special nominal roll. It is almost certain that someone's next of kin will have to be contacted while the unit is overseas. Great care should be taken in writing to next of kin and the fewer people that write after someone has been killed the better. This will ensure that details are correct and that next of kin are spared unnecessary, and sometimes untrue, harrowing accounts. When a death is the subject of a Board of Inquiry no details may be given to the next of kin as long as the matter is sub-judice:

In considering next of kin their financial position has to be thought of. Apart from the voluntary allotments made by soldiers the attention of all ranks must be directed to ensuring that they review any arrangements for their wives to have sufficient money. The need for a will and the ways of making one must also be understood. The advantages of insurance, both life (Military Widows' Fund, Soldiers' Widows Fund) and kit should be pointed out.

Documentation of personnel. All personnel documentation must be reviewed and brought up-to-date where nc cessary. The time factor is most important if passports are necessary.

Civilian employment and hobbies. It is quite amazing the number of semi-skilled painters, carpenters, bricklayers, plumbers, builders, writers, barbers and even engine drivers that will turn up if the civilian jobs of the men are examined. Occasionally knowledge of a relevant foreign language will te uncovered, particularly where somebody has been in the overseas country before. It is also important to know how many members of the Unit hold driving licences apart from RCT personnel.

Unit standing orders. If standing orders exist they must be brought up-to-date on 
adding a section relevant to the unit overseas. If such orders do not exist they must be prepared at least in outline: duties of various personnel, orders relating to dress including battle order and contents of the small pack, and orders on security of arms and ammunition.

Load tables. Load tables are one of the keys to the efficiency of a mobile unit. Primarily they are vehicle load tables showing the tactical loading of personnel and equipment. In the circumstances under discussion there is likely to be a need for separate aircraft load tables.

Fitting of tropical uniform. Tropical uniform will be issued in UK and it will be necessary to have fitting parades. Even putting on puttees presents a problem to most people who haven't worn them before.

Directional signs. The unit will need to be sign-posted in its overseas locations and directional signs should be made in UK before departure.

Advance, main and rear parties. The move of the unit will be planned, in outline, in three parts, advance, main and rear parties. The Commanding officer should go on the advance party in order to make an early appreciation of the situation at the other end. He should contact the DMS/DDMS soon after arrival overseas in order to learn about local medical conditions and to give an account of the state of the field ambulance. On occasion, the rear party may remain in U.K.

Blood grouping. There is ample time to blood group all ranks of the field ambulance and this should be done and recorded.

Quartermaster and transport officer. Because of the preparations for the move the quartermaster and transport officer should be kept as much as possible to their own particular sphere. It is important that they are given early information about priorities of stores and vehicles and that they are told the last date after which neither stores nor transport will be required for training schemes.

Officers' special duties. The duties of PMC are usually undertaken by the secondin-command and he should devise ways of improving the rather meagre mess equipment provided. Mess rules should be reviewed. Officer i/c Sergeants' Mess Account-this appointment is probably best carried out by the non-medical officer who does not hold the imprest account. He must ensure there are rules for the Mess. The second-in-command is also President of the Regimental Institute and is committee chairman. The members come from rank and file representatives of each part of the unit. The committee should consider very carefully what will be required overseas. Footballs to kick around and cricket bats and balls are obvious " musts ". Indoor games, battery operated radios and gramophones should be thought of. Books for a library might also be purchased. It may also be necessary to organise a unit canteen in the absence of NAAFI facilities: Messingonce the unit is in the field this is theoretically a matter for the quartermaster, but there is much to be said for one of the junior medical officers being messing officer. Each rank and file member of the committee comes from a different part of the unit and the senior nco cook is always present. Sports Officer-there is usually no dearth of accomplished sportsmen among the medical officers and one of them should be appointed sports officer. After discovering the sporting interests of the unit he should decide what sports to concentrate on and get the necessary equipment from the PRI: Education officer-the move overseas will affect personnel studying for Army Certificates of Education and it will be necessary to find out about overseas facilities. The education officer should also read up something of the history and customs of the country to which the unit is going 
and be able to brief all ranks. He would also be concerned with encouraging clubs for hobbies, e.g. a camera club. NBC officer - the officer selected for this appointment should be sent away on a short course. He could also undertake the duties of fire officer.

Arrangements for families at the UK station. In many' cases arrangements for families will be co-ordinated by Brigade Headquarters and there may be a wives meeting and a wives club. If the brigade is leaving rear parties in UK the situation is simplified. The problem is not only loneliness of an individual wife, but also the difficulties of getting out shopping or taking a child to school when there are very young children in the family. Arrangements might be made for school and shopping buses and even for a crểche for young children. All wives must know whom to approach for help if they are worried or in difficulties. Much of all this is going to fall on the officers wives and they should be prepared for it. The officer or soldier overseas will feel much happier if he knows his wife is part of an organised community in which she can turn to other pecple for help. If the unit leaves a rear party officer in UK he will be responsible for sending a weekly liaison letter to the commanding officer and this will contain any relevant information about families.

\section{Intensive Training Programme}

In order to ascertain the training state of the unit, as well as to revise certain subjects, the commanding officer would arrange as soon as possible a short, intensive, training programme. He is fighting against time but could achieve his objects by a 14 day all ranks training programme, covering some 98 hours including Saturdays and Sundays. The programme would be based on the following lines:

All ranks take part in route marches and 16 hours are allotted for these. They produce determination, good man-management, and get the unit together as a team. On the longest ones the cooks would be out in transport and prepare a meal with the field cooking equipment. At the end of each march the officers would not fall out until they had inspected their men's feet, seen that hot showers and clothes-drying facilities were available for them and that a hot meal was ready.

Some 14 hours are given to section commanders' disposal. This is to enable the section officers to get to know their men, to review training, to study equipment and packing.

On one occasion the ADS and sections are deployed and set up.

Other subjects are allowed for as follows: first aid (10 hours); blood transfusion (4 hours); plaster technique (4 hours); Army Health (4 hours); physical training (6 hours); organised games ( 3 hours); tent pitching ( 3 hours); vehicle loading ( 3 hours); loading casualties on helicopter (3 hours); flight convoy (3 hours). Talks are given on the organisation and function of the field ambulance, nuclear warfare, current affairs and duties in aid of the civil power. As much time as possible should be given to map reading and every effort should be made to obtain maps of the country to which the brigade is going. There is a padre's hour each week.

Much of this programme is only applicable to RAMC personnel. The transport officer would have a separate programme for RCT and REME personnel. He would also give instruction in weapon handling to those RAMC who are armed.

Almost all the points in this paper are equally applicable to a brigade going to a temperàte climate and, indeed, going to war. In the latter instance, of course, the threat of an ever-present enemy at home and overseas will place more emphasis on training 
concerned with survival-digging, camouflage, movement by night. In war there is another factor, age, or rather youth. The young officer in peace becomes the commanding officer in war: he must realise this and prepare himself for it.

\section{SENIOR APPOINTMENT}

\section{Director, Army Dental Service}

Colonel W. F. FINLAYSON, O.B.E., L.D.S., takes over the appointment of Director, Army Dental Service, in succession to Major-General A. N. MOON, C.B.E., L.D.S., in June, 1966, with the rank of Major-General.

William Forbes Finlayson was born in Edinburgh on 12 th Octóber, 1911, and was educated at George Heriots School, Edinburgh. He graduated as a Licentiate in Dental Surgery at the Edinburgh Dental Hospital, Royal College of Surgeons, Edinburgh in 1933.

He was commissioned in the Army Dental Corps (now Royal Army Dental Corps), on 18 th February, 1935, and has served at home, in Malaya, Middle East (Egypt) and in the British Army of the Rhine. Mentioned in Despatches 1946, he was awarded the O.B.E. in 1955 and is married with two children.

At present he is Specialist Dental Officer at the Military Hospital, Colchester, Essex.

\section{RAMC/BMA LUNCH 1966}

The annual lunch for past and present R.A.M.C. officers will be held at Birks Hall of Residence (University of Exeter) New North Road, Exeter, during the course of the BMA Annual Representative Meeting.

The President of the British Medical Association and the Director General Army Medical Services have been invited to be present and the R.A.M.C. Staff Band will be in attendance.

Time and date: 12.15 for 12.45 pm; Tuesday 5 th July, 1966

Tickets: Price $21 /$ from Luncheon Secretary.

(Colonel R. H. Robinson, M.D., T.D.) c/o No. 1 Coy, RAMC, Aldershot; Hants up to 1 st July, thereafter from BMA Registration Office at the University of Exeter. 